\title{
An Investigation Profile in Pediatric Patients Suspected of Acute Hepatitis A
}

\author{
Geetika Rana (iD) and Owias Yousf Lone* (D) \\ Department of Microbiology, SGRRIM \& HS Patel Nagar, Dehradun, India.
}

\begin{abstract}
Hepatitis A virus (HAV) infection is one of the important causes of hepatitis in developing countries. It is transmitted through feco-oral route. This poses major health problems in children. Serum samples of the patients from pediatrics department suspected of acute viral hepatitis presenting with clinical features like fever, nausea, vomiting, and jaundice werecollected and analyzed by using commercially available mini VIDAS 307 (Biomeriux) to detect anti HAV IgM antibodies. A nine months prospective study was conducted in the Department of Microbiology and immunology of Shri Guru Ram Rai Institute of Medical and health science Dehradun, India. Of the 47 serum samples received during the study period, 23 (48.93\%) were found tobe positive for anti-HAV IgM (VIDAS 307 Biomeriux). The prevalence was found to be more in male patients than in female patients, that is, $14(60.8 \%)$ and $9(39.13 \%)$ respectively, and was predominantly seen in the $5-10$ years of the age group (60\%). Peak cases were found in the month of October and November. The study showed a high positivity $(48.93 \%)$ of HAV in this sub-Himalayan region indicating the role of preventive measures including safe drinking water, improved sanitation and vaccination in preventing infection. Thus, detection of anti-HAV IgM becomes the cornerstone entity for diagnosis.
\end{abstract}

Keywords: Hepatitis A, Anti-HAV IgM, children

*Correspondence: owaislone1993@gmail.com

(Received: February 06, 2021; accepted: August 03, 2021)

Citation: Rana G, Lone OY. An Investigation Profile in Pediatric Patients Suspected of Acute Hepatitis A. J Pure Appl Microbiol. 2021;15(4):2098-2102. doi: 10.22207/JPAM.15.4.32

(C) The Author(s) 2021. Open Access. This article is distributed under the terms of the Creative Commons Attribution 4.0 International License which permits unrestricted use, sharing, distribution, and reproduction in any medium, provided you give appropriate credit to the original author(s) and the source, provide a link to the Creative Commons license, and indicate if changes were made. 


\section{INTRODUCTION}

Hepatitis A virus (HAV) was discovered in 1973 and is mainly responsible for pediatric hepatitis seen throughout the world, predominantly in developing countries. Hepatitis A is typically transmitted by feaco-oral route. Mostly transmission of Hepatitis A occurs by ingestion of contaminated water or food, sharing contaminated utensils with a person infected with $\mathrm{HAV}^{1}$. As per WHO, $90 \%$ of children under 10 years of age get infected with Hepatitis A virus in developing nations. ${ }^{2}$

The incubation period of hepatitis A is usually 28 days (range 15 to 50 days). ${ }^{12}$ The symptoms of HAV infection rank from moderate to severe and can involve jaundice, fever, loss of appetite, malaise, diarrhea, abdominal discomfort, nausea and dark colored urine. However, not everyone who is infected has all the symptoms. The person who has not been vaccinated or previously infected can get infected with HAV in endemic areas. Mostly hepatitis A virus infects children with risk factors such as poor sanitation, no access to safe drinking water and incomplete immunization.

Hepatitis A infection is rarely fatal or chronic. But the clinical manifestations may progress to debilitating symptoms and fulminant hepatitis. Hepatitis A infections can be sporadic as well as in epidemics world-wide. Hepatitis $A$ is one of the most frequent causes of food borne infection. India is hyper-endemic for hepatitis $A$ and $E$. Many outbreaks of viral hepatitis have occurred in different parts of India since its first officially reported epidemic at Delhi in $1955 .{ }^{3}$ The disease generally leads to significant economic and social burden in developing communities. Recovery can take weeks or months before people can resume work, school or daily life.

This study was undertaken to determine the prevalence, clinical and biochemical profile of hepatitis A infection in children in Uttarakhand.

\section{MATERIAL AND METHODS}

This was a prospective cross sectional study carried out in the department of microbiology and immunology of SGRRIM \& SH, Patel Nagar, Dehradun from September 2018 to May 2019. Ethical approval was obtained from the Institutional Ethics Committee (Reference no SGRR/IE133/21). After taking informed consent from parents/guardian, 47 children suspected of acute viral hepatitis were included in this study. Acute viral hepatitis was defined as an acute illness typically including acute jaundice, dark urine, anorexia, malaise, extreme fatigue, right upper quadrant tenderness, increased urine urobilinogen and $>2.5$ times the upper limit of serum alanine aminotransferase. Hepatitis A was diagnosed by the presence of anti-HAV IgM in the serum. All samples were tested for anti HAV IgM by Enzyme Linked Florescent Assay (ELFA) in VIDAS 307 (biomerieux) as per laboratory standard operating procedure. Test value of $\geq 0.5$ was considered positive and lesser than $<0.4$ was considered negative. Test values $\geq 0.4$ and $<0.5$ were equivocal, which were repeated.

Statistical analysis was performed using SPSS software version 20.

\section{RESULT}

Of the 47 serum samples received, 23 (48.93\%) patients were positive for anti-HAV IgM. Out of these 23 positive samples, 14 (60.8\%) were male and 9 were female patients (39.13\%) (Table 1). Majority of cases belonged to $5-10 \mathrm{yrs}$ age group (60\%) (Table 2). The most common clinical presentation was fever (82.60\%) followed by jaundice $(78.26 \%$ ) and abdominal pain $(78.26 \%)$ (Table 5).

Table 1. Gender distribution of Anti-HAV IgM Seropostive cases

\begin{tabular}{lcc}
\hline Gender & $\begin{array}{c}\text { HAV Suspects } \\
n(\%) n=47\end{array}$ & $\begin{array}{c}\text { HAV Positive } \\
n(\%) n=23\end{array}$ \\
\hline Male & $30(63.8)$ & $14(60.8)$ \\
Female & $17(36.17)$ & $9(39.13)$ \\
\hline
\end{tabular}

Table 2. Age wise distribution of Anti-HAV IgM positive cases

\begin{tabular}{lcc}
\hline $\begin{array}{l}\text { Age group } \\
\text { suspected }\end{array}$ & $\begin{array}{c}\text { Total HAV } \\
\text { suspects n=47 }\end{array}$ & $\begin{array}{c}\text { Positive Anti HAV } \\
\text { IgM cases. } n=23\end{array}$ \\
\hline $0-5$ Yrs & 10 & $6(26 \%)$ \\
$5-10$ Yrs & 18 & $14(60 \%)$ \\
$10-15$ Yrs & 14 & $3(13.04 \%)$ \\
$15-18$ Yrs & 5 & $0(0 \%)$ \\
\hline
\end{tabular}


Table 3. Month wise distribution of AVH and Anti-HAV IgM positive

\begin{tabular}{lcc}
\hline Month & $\begin{array}{c}\text { HAV suspected } \\
\text { Patients }\end{array}$ & $\begin{array}{c}\text { Positive for Anti- } \\
\text { HAV IgM }\end{array}$ \\
\hline Sep. 2018 & 03 & 03 \\
Oct. 2018 & 10 & 4 \\
Nov. 2018 & 12 & 6 \\
Dec. 2018 & 6 & 1 \\
Jan.2019 & 4 & 2 \\
Feb. 2019 & 3 & 0 \\
Mar. 2019 & 2 & 1 \\
Apr. 2019 & 2 & 1 \\
May. 2019 & 5 & 5 \\
Total & 47 & 23 \\
\hline
\end{tabular}

Table 4. Distribution of OPD and IPD suspected cases

\begin{tabular}{lcc}
\hline Department & Number & Percentage \\
\hline OPD & $1(n=5)$ & $4.34 \%$ \\
IPD & $22(n=42)$ & $95.64 \%$ \\
Total & $23(n=47)$ & $100 \%$ \\
\hline
\end{tabular}

Most cases 11 (47.8\%) had total bilirubin in the range of $5-10 \mathrm{mg} / \mathrm{dl}$, liver enzymes were elevated in all cases, most cases Aspartate Aminotransferase (AST) and Alanine transaminase (ALT) levels were found to be $>1000$ (78.02\% and $65.21 \%$ respectively). Serum alkaline phosphatase levels were found increased in $100 \%$ cases, while serum albumin levels were found to be decreased in $43.47 \%$ cases. (Table 6 ).

\section{DISCUSSION}

A total of 47 patients were included in this study and were screened for hepatotropic viral marker namely Anti-HAV IgM. 23 (48.9\%) of them were found positive for the hepatitis $A$ infection. ${ }^{5}$ In our study, majority of the seropositive patients were from the In-patient department IPD (95.4\%). HAV infection was detected throughout the time period of nine months. This is probably due to unhygienic practices, lack of clean drinking water facility in Dehradun region. During the study period, $10(43.47 \%)$ cases were positive in month of October to November. This is not in agreement with the studies done by Manas Ranjan Behera, Lipilekha Patnaik (33.30\%) and Rachna Tewari, Vaishali Makeeja, Mridu Dudeja at New Delhi that
Table 5. Clinical features of Anti HAV IgM Positive cases $(n=23)$

\begin{tabular}{lcc}
\hline Clinical Feature & Present & Percentage \\
\hline Fever & 19 & 82.60 \\
Abdominal pain & 18 & 78.26 \\
Jaundice & 18 & 78.26 \\
Nausea & 16 & 69.56 \\
Vomiting & 14 & 60.86 \\
Dark colored urine & 7 & 30.43 \\
Altered sensorium & 4 & 17.39 \\
\hline
\end{tabular}

Table 6. Biochemical parameters of Anti-HAV IgM positive cases

\begin{tabular}{ll}
\hline Parameters & $\begin{array}{l}\text { Anti-HAVIgM positive } \\
\text { cases }(\mathrm{n}=23)\end{array}$ \\
\hline $\begin{array}{l}\text { Total serum bilirubin }(\mathrm{mg} / \mathrm{dl}) \\
<5\end{array}$ & $9(39.13 \%)$ \\
$5-10$ & $11(47.8 \%)$ \\
$>10$ & $3(13.04 \%)$ \\
AST (u/l) & \\
$<500$ & $3(13.04 \%)$ \\
$500-1000$ & $2(8.69 \%)$ \\
$>1000$ & $18(78.02 \%)$ \\
ALT(u/l) & \\
$<500$ & $3(13.04 \%)$ \\
$500-1000$ & $5(21.7 \%)$ \\
$>1000$ & $15(65.21 \%)$ \\
Elevated ALK $\mathrm{P}(\mathrm{u} / \mathrm{l})$ & $23(100 \%)$ \\
S. Albumin $(<3.5$ gm/dl) & $10(43.47 \%)$ \\
\hline
\end{tabular}

showed more cases in month of July to August (26.6\%). ${ }^{6,4}$ The reason for this variation could be due to different geographical location and untimely rains in Uttarakhand region. Our study showed higher seropositivity in males $(60.8 \%)$ as compared to females $(39.13 \%)$. A total of $60 \%$ of seropositive cases were in the age group of 5-10 years which is similar to study done in eastern India that reported higher prevalence in age group 5 to 10 years (62.5\%). ${ }^{7}$ Different results were reported by study done by Nandi B showing only $8.10 \%$ patients positive below the age of 10 years. ${ }^{8}$ In our study maximum numbers of patients presented with fever (82.60\%) which is dissimilar to study done by Girish $N$ which has reported $100 \%$ patients presenting with fever. ${ }^{9}$ Jaundice was seen in 18 (78.26\%) cases which approximately was similar with studies done in Bangalore showing 83.3\% 
patients complaining about jaundice. ${ }^{9}$ Complaints of vomiting were reported by 14 patients (60\%) which is similar to the study done in Bangladesh $(89 \%) .^{10}$

Most cases (47.8\%) had total bilirubin $5-10 \mathrm{mg} / \mathrm{dl}$ which is dissimilar to the studies done by Nandi B showing total bilrubin level $>10 \mathrm{mg} /$ dl for most of the cases. ${ }^{8}$ Liver enzymes were elevated in all cases, most cases AST and ALT levels were found to be $>1000$ (78.02\% and $65.21 \%$ respectively). While studies done at Odisha and Bangladesh had reported that maximum cases with AST $(70.8 \%)$ and ALT $(54.1 \%)$ level $<500$ thus dissimilar to our results. ${ }^{6,10}$ Serum alkaline phosphatase levels were found increased in $100 \%$ our cases which is not in agreement with the studies done in Odisha (52\%). ${ }^{6}$ In our study it was observed that none of the 23 seropositive cases were vaccinated against hepatitis $A$ indicating that although the vaccines are available but people are not vaccinating their children. This is due to the fact that the people of this area are either not aware of the availability of vaccine, or they do not know its importance.

\section{CONCLUSION}

Hepatitis $A$ is the most common cause of viral hepatitis in children. The finding of the current study indicates that HAV infection is a disease of great concern in this part of the state of Uttrakhand with prevalence of $48.93 \%$ in suspected HAV patients. In spite of availability of an effective vaccine, the seroprevalance of HAV in our country is still high. Low socioeconomic status, unhygienic practices and unawareness amongst the population are the most important factors responsible. Hence, the detection of anti HAV IgM antibodies in suspected patients remains the cornerstone entity for making correct and timely diagnosis. Measurement of the various liver function tests also help in the management, prognosis and follow up of the patients.

\section{ACKNOWLEDGMENTS}

None.

\section{CONFLICT OF INTEREST}

The authors declare that there is no conflict of interest.

\section{AUTHORS' CONTRIBUTION}

Both the authors listed have made a substantial, direct and intellectual contribution to the work and approved it for publication.

\section{FUNDING}

None.

\section{DATA AVAILABILITY}

The datasets generated during and/or analysed during the current study are available from the corresponding author on reasonable request.

\section{ETHICS STATEMENT}

Ethical approval was obtained from the SGRR Institutional Ethics Committee REGISTRATION NO. ECR/710/Inst/UK/2015/RR-18 REF NO: SGRR/ IEC133/21.

\section{REFERENCES}

1. CDC. Hepatitis A. Center for disease control and prevention. www.cdc.gov/hepatitis/hav/index.htm. (Acessed on 31 May 2021)

2. WHO. What is hepatitis? World health organization. http://www.who.int/features/qa/76/en/.

3. Gupta A, Chawla Y. Changing epidemiology of hepatitis A infection. Indian J Med Res. 2008;128(1):7-9. PMID: 18820351.

4. Tewari R, Makeeja V, Dudeja M. Prevalence of hepatitis A in southern part of Delhi, India. Int J Med Sci Public Heal. 2016;5(10):2067-2070. doi: 10.5455/ ijmsph.2016.20112015426

5. Das M, Mili MK. Spectrum of Acute Hepatitis in Children at a Tertiary Care Hospital. IOSR J Dental and Med Sci. 2019;18(5):73-75.

6. Behera MR, Patnaik L. Clinico-biochemical profile and etiology of acute viral hepatitis in hospitalized children: A study from Eastern India. Indian J Child Heal. 2016;3(4):317-320. https://doi.org/10.32677/ IJCH.2016.v03.i04.012

7. Shavakhi A, Somi MH, Farhang S, Majidi G, Majidi T, Pouri AA. Prevalence of hepatitis A in Iranian patients with chronic liver disease. Iranian Journal of Clinical Infectious Diseases. 2008;3:189-192.

8. Nandi B, Hadimani P, Arunachalam R, Ganjoo RK. Spectrum of Acute Viral Hepatitis in Southern India. Med J Armed Forces India. 2009;65(1):7-9. doi:10.1016/S0377-1237(09)80044-0

9. Girish N, Sunil B, Devaranavadagi RA. A clinical study of viral hepatitis in children: a prospective hospital-based study. Int J Contemp Pediatr. 2018;5(2):563-568. doi: 10.18203/2349-3291.ijcp20180555

10. Salahuddin M, Syed SA, Manzoor H, Mahenaz A, Farhana T. Recent Spectrum of Acute Viral Hepatitis in Children: An Experience in a Tertiary Centre of Bangladesh. Adv 
Rana \& Lone | J Pure Appl Microbiol | 15(4):2098-2102 | December 2021 | https://doi.org/10.22207/JPAM.15.4.32

Res Gastroentero Hepatol. 2017;6(3):555686. doi: 10.19080/ARGH.2017.06.555686

11. Bhatt VR, Barure RB. A Study of the Demography, Etiological Profile and Risk Factors of Acute Viral Hepatitis in an Urban Setting. Nat/ J Community Med. 2017;8(12):745-749.
12.

CDC. Hepatitis A.Center for disease control and prevention. https://www.cdc.gov/vaccines/pubs/ pinkbook/hepa.html\#: :text=The\%20incubation\%20 period $\% 20$ of $\% 20$ hepatitis, $\% 2$ C $\% 20$ dark $\% 20$ urine\%2C\%20and\%20jaundice (Accessed on 31 May 2021) 